\title{
Editorial
}

Paul R. McDaniel, Hill \& Barlow, Boston

\section{Bashing foreigners}

The change in the United States' position in the world economy from one of dominance over and independence from the economies of other countries to one of parity (or less) and interdependence with those economies is being made with considerable stress on various foci of international economic relations. One focus has been on the pressure for greater protection of US industries from foreign competition. Another has been on the level of foreign investment in the US; indeed a recent Gallup poll found that 70 per cent of the American public hold the view that foreign investment in the US 'is a bad thing'.

Inevitably, the tax system has been subjected to similar pressures. And, in my view, the results have been unfortunate in the context of applying US rules to non-US citizens who invest, do business and even live in the country. Only twenty years ago a leader in the movement to develop norms and generally applicable tax principles in the international tax context, the US in recent tax legislation has displayed an increasing jingoism and willingness to flout international law.

One of the more distasteful bits of tax insularity was sprung on an unsuspecting public in the Technical and Miscellaneous Revenue Act of 1988 (TAMRA). This was the provision that amended the wealth transfer taxes to deny the marital deduction ${ }^{1}$ for property passing from a US citizen spouse to a non-US citizen spouse. The new rules mean, for example, that if deceased spouse $\mathrm{A}$, who is a US citizen, bequeaths $\$ 2$ million to his or her surviving spouse, who is and has for many years been a US resident (fully subject to income and gift taxes), no marital deduction will be allowed and the full $\$ 2$ million will be subject to estate tax. The net of tax amount will be subject to estate tax again on the death of the second spouse. On the other hand, deceased spouse B whose spouse is a US citizen can transfer the same $\$ 2$ million estate tax free to his or her surviving spouse (tax will be imposed in the death of this spouse). ${ }^{2}$

The 'justification' offered for this provision was that an alien resident surviving spouse could take the property outside the US estate tax jurisdiction by returning to his or her own country, presumably something a US citizen could not do. If the estate of the deceased spouse is granted a marital deduction, the property would never be subject to US estate tax. The new rules prevent this result. The problem is that neither the stated premises nor the result is correct. First, a US citizen surviving spouse who renounces citizenship and moves to another country for non-tax avoidance reasons is not subject to US estate tax except on US situated property; ${ }^{3}$ no US estate tax will ever be collected in this situation either if the property is not situated in the US and the estate of the US citizen spouse has used the unlimited marital deduction. Second, neither a US citizen nor resident alien surviving spouse who leaves the US escapes US estate tax on US situated property owned at death, e.g. US real estate and stocks in US corporations. Third, under the new legislation, a US spouse can transfer $\$ 600,000$ plus $\$ 100,000$ per year gift tax free to his or her resident alien spouse. If those funds are invested in US Treasury obligations or bonds and debentures of US corporations which qualify for the income tax exemption for portfolio interest, the alien resident surviving spouse can sail happily home free of any US gift or estate tax-precisely the situation the legislation was supposed to stop. The US may wring some estate tax out of 'foreigners' - those surviving spouses who cannot or do not want to leave the country - but in a pattern that is truly capricious and unprincipled. ${ }^{4}$

\footnotetext{
1 The general rule permits property to pass from one spouse to the other free of any estate or gift tax.

2 Some relief is provided to A if A employs a 'qualified domestic trust', but the qualifying conditions make the vehicle cumbersome and inflexible at best.

${ }^{3}$ Section 2107 imposes the estate tax on the taxable estate of a non-resident alien if that person dies within ten years after losing US citizenship and the loss had as one of its principal purposes the avoidance of US wealth transfer or income taxes. If a problem exists with respect to resident alien spouses, expansion of Section 2107 would have been to approach preferable to that adopted.

${ }^{4}$ Ironically, of course, the true economic losses under the statute are children born in the US who happen to have one non-US citizen parent; they, as the result of poor parent selection, receive their estates after two taxes have been paid.
} 
The other distressing aspect of recent US international tax legislation is the increasing willingness by Congress deliberately to violate international law by overriding our tax and FCN treaties. Under the US Constitution, treaties and legislation are equal in force; thus where a treaty provision is in conflict with a provision in the Internal Revenue Code, the later in time prevails. Equally important, under court-established rules, Congress must clearly express its intention to override a conflicting treaty provision since Congress is presumed to take seriously our country's obligations to its treaty partners.

US concern for its tax treaty obligations may have reached a high mark with the Foreign Investors Tax Act of 1966. The 1966 Act contained a specific provision that the Act did not apply if its application would be contrary to US tax treaty obligations. But beginning in 1976, Congress has shown an increasing predilection to override pre-existing treaty obligations. Perhaps the best known is the override provision in FIRPTA (but, at least Treasury was given five years to rewrite existing treaties). The 1986 Tax Reform Act retroactively provided that certain source rules contained in the 1984 Act were to override contrary treaty provisions, whether the treaty was entered into before or after the 1984 Act (post-1984 Act treaties could override the source rules if done so by specific reference to the relevant Code provision). The 1986 and 1988 Acts continued the override trend, although strong objections from a variety of sources helped prevent still worse results. The overrides have mostly occurred as the US has moved to a more mature source-based tax jurisdiction. Some readers may recall past high minded lectures from the US to countries which departed from generally agreed upon source rules solely for revenue reasons.

I do not here address whether the substantive provisions that overrode prior treaty obligations represented sound tax policy for the US. My point is that, in each and every override instance, the US was and is violating international law. To those in the US who believe that the US should be a leader in establishing and strengthening the rule of international law rather than violating it, this recent Congressional tendency is an unhappy one indeed. Our treaty partners have every right to be upset at the recent breaches of treaty obligations and international law.

US international tax rules and relationships represent only a part of the country's complex web of international economic relations. But it will be unfortunate if the changing role of the US in those relations infects its tax system with anti-foreign, international law violating rules. 